\title{
Short-term Flooding Affects Gas Exchange Characteristics of Containerized Sour Cherry Trees
}

\author{
Thomas G. Beckman ${ }^{1}$, Ronald L. Perry ${ }^{2}$, and James A. Flore ${ }^{3}$ \\ Department of Horticulture, Michigan State University, East Lansing, \\ MI 48824
}

Additional index words. Prunus cerasus, P. mahaleb, photosynthesis, transpiration, anaerobiosis, hypoxia

\begin{abstract}
The effects of short-term soil flooding on gas exchange characteristics of containerized sour cherry trees (Prunus cerasus L. cv. Montmorency /P. mahaleb L.) were studied under laboratory conditions. Soil flooding reduced net $\mathrm{CO}_{2}$ assimilation (A) within 24 hours. Net $\mathrm{CO}_{2}$ assimilation and residual conductance to $\left.\mathrm{C}_{(}^{\prime}\right)$ declined to $\approx 30 \%$ of control values after 5 days of flooding. Effects on stomatal conductance to $\mathrm{CO}_{2}\left(\mathrm{~g}_{\mathrm{s}}\right)$ and intercellular $\mathrm{CO}_{2}\left(\mathrm{C}_{\mathrm{i}}\right)$ were not significant during the 5 days of treatment. Apparent quantum yield $(\Phi)$ gradually declined to $52 \%$ that of controls during these 5 days. In a second experiment, $\mathrm{CO}_{2}$ response curves suggested that, initially, stomatal and nonstomatal limitations to A were of about equal importance; however, as flooding continued, nonstomatal limitations became dominant.
\end{abstract}

Soil flooding of fruit trees generally causes a rapid decline in stomatal conductance, often in conjunction with reduced $\mathrm{CO}_{2}$ assimilation (Andersen et al., 1984a, 1984b; Crane and Davies, 1989; Davies and Flore, 1986a; Phung and Knipling, 1976; Schaffer and Ploetz, 1989; Smith and Ager, 1988; Sy-

Received for publication 30 Oct. 1991. Accepted for publication 1 July 1992. Acknowledgement is made to the Michigan Agricultural Experiment Station for their support of this research. This research was funded in part with USDA Grant no. 88-34132-3380. The cost of publishing this paper was defrayed in part by the payment of page charges. Under postal regulations, this paper therefore must be hereby marked advertisement solely to indicate this fact.

${ }^{1}$ Former Research Assistant. Present address: Southeastern Fruit and Tree Nut Research Laboratory, USDA-ARS, P.O. Box 87, Byron, GA 31008.

${ }^{2}$ Associate Professor.

${ }^{3}$ Professor. vertsen et al., 1983). Initial declines in stomatal conductance are not usually accompanied by a drop in leaf water potential (Andersen et al., 1984b; Davies and Flore, 1986b, 1986c; Smith and Ager, 1988), suggesting some mechanism other than leaf desiccation as the cause. Reductions in $\mathrm{CO}_{2}$ assimilation have been attributed to stomatal and/or nonstomata1 limitations (Davies and Flore, 1986a, 1986b, 1986c; Phung and Knipling, 1976; Smith and Ager, 1988). However, Schaffer and Ploetz (1989) have suggested that $\mathrm{CO}_{2}$ assimilation limits stomatal conductance in avocado (Persea americana Mill.) during flooding.

Models of leaf gas exchange have been developed that allow evaluation of the presence and relative contribution of stomatal and nonstomatal limitations to net $\mathrm{CO}_{2}$ assimillation (A) in stressed plants (Farquhar and Sharkey, 1982; Farquhar and von Caemmerer, 1982; Farquhar et al., 1980; Jones, 1973; von Caemmerer and Farquhar, 1981). 


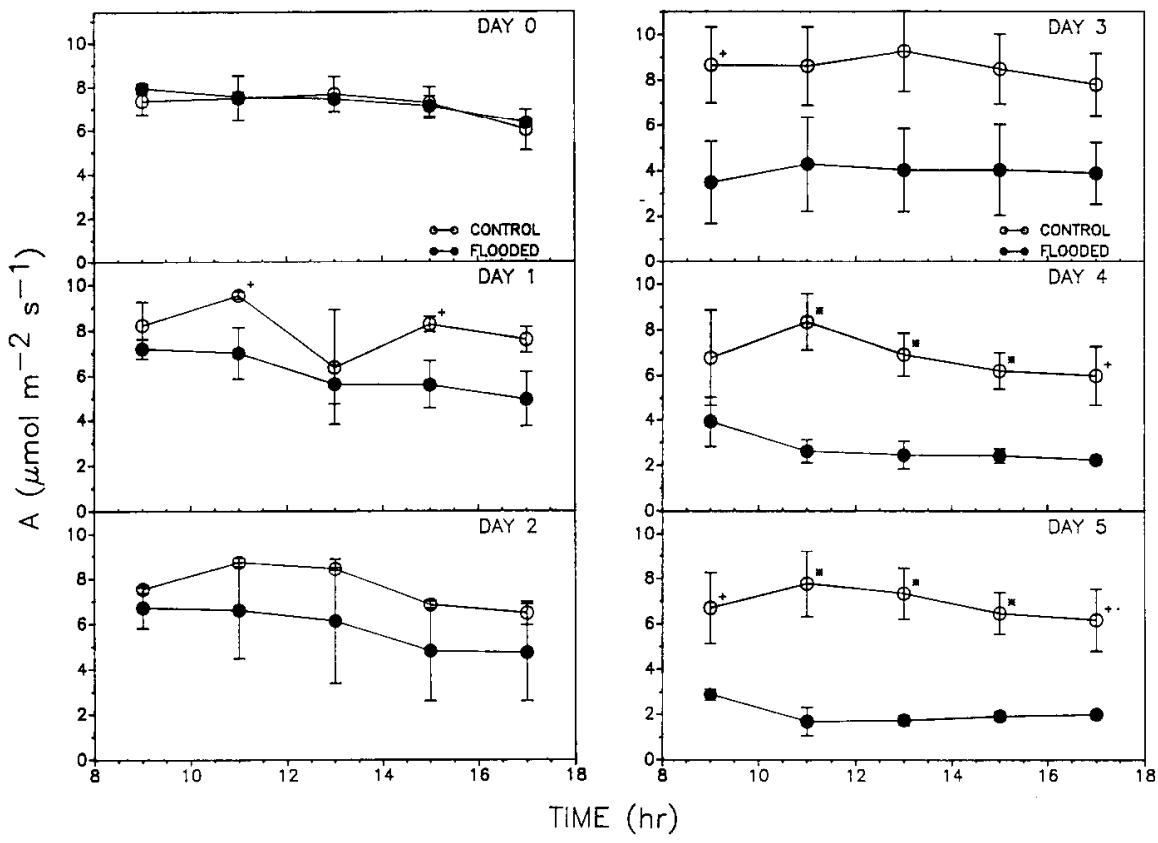

Fig. 1. Effects of 1 to 5 days of flooding on net $\mathrm{CO}_{2}$ assimilation (A) of sour cherry trees. Data points are means of two plants/time $\pm \mathrm{SD}\left[{ }^{+*}\right.$ indicate significance at $P=0.10\left(^{+}\right)$and $0.05\left(^{*}\right)$, otherwise nonsignificant, $\mathrm{F}$ test].

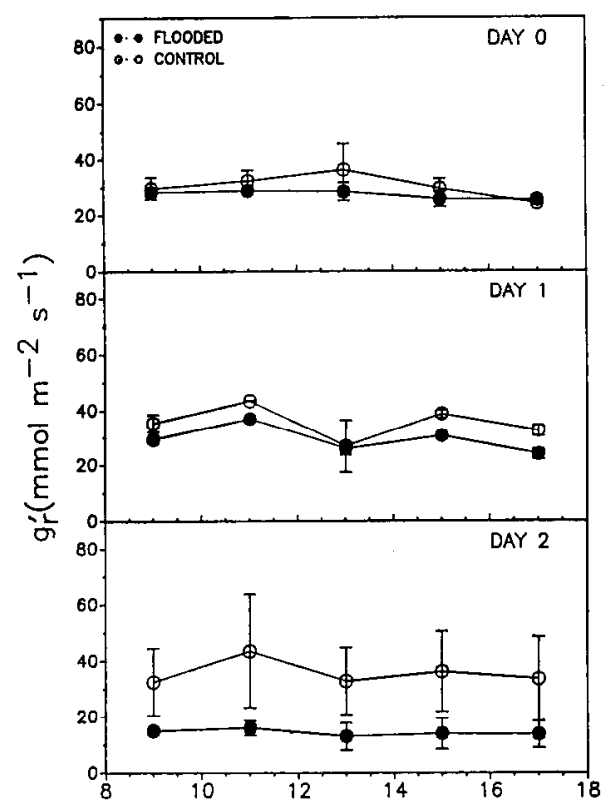

TIME (hr)

Fig. 2. Effects of 1 to 5 days of flooding on residual conductance to $\mathrm{CO}_{2}\left(\mathrm{~g}_{r}{ }^{\prime}\right)$ of sour cherry trees. Data points are means of two plants/time $\pm \mathrm{SD}\left[{ }^{+, *}\right.$ indicate significance at $P=0.10\left(^{+}\right)$and 0.05 $\left({ }^{*}\right)$, otherwise nonsignificant, $\mathrm{F}$ test].

The objectives of this series of experiments were to characterize the effects of soil flooding on gas exchange of sour cherries under controlled conditions and to estimate the relative importance of stomatal and nonstomatal limitations to A during flooding.

Materials. Dormant, budded, sour cherry trees ('Montmorency'/Mahaleb) were planted in 7-liter plastic containers filled with a steamsterilized mineral soil mix [ $\approx 50 \%$ sandy loam, $30 \%$ spaghnum peat, $20 \%$ sand (by volume)] and placed in a shaded greenhouse $(\approx 60 \%$ full sun). Trees were watered every other
Diurnal response of gas exchange characteristics (Expt. 1). Four trees were brought from the greenhouse to the laboratory the evening before the start of experiment. Trees were selected on the basis of uniformity of A of a single midcanopy leaf as measured in the greenhouse with a portable gas analyzer system (Analytical Development Co., Hoddeston, U.K.). All plants had ceased active shoot growth several weeks previous. Plants were placed in a walk-in growth chamber (Model PGV36; Conviron Systems of America, Pembina, N.D.) set on a 12 -h photoperiod (0800-2000 HR; light provided by a bank of cool-white fluorescent and incandescent bulbs suspended above plants), day/ night cycle of $25 / 20 \mathrm{C}$, and relative humidity (RH) of $50 \%$.

A randomly selected, fully expanded leaf (5 to 6 weeks old) in the upper half of each tree was sealed in an environmentally controlled plexiglass chamber (Sams and Flore, 1982) for gas exchange measurements (A, $\mathrm{g}_{\mathrm{s}}, \mathrm{g}_{\mathrm{r}}^{\prime}$, and $\left.\mathrm{C}_{\mathrm{i}}\right)$. Measurements were made every 2 h (0900-1700 HR) using an open gas-exchange system described by Sams and Flore (1982), except for the substitution of an infrared (IR) gas analyzer (Model 225MK3, Analytical Development Co.) and the use of a Multiple Dyna Blender (Model 8219; Matheson Instruments, Horsham, Pa.) equipped with mass flow controllers to control air flow through individual leaf chambers. Measurements were made within optimum environmental conditions for gas exchange in sour cherries (Sams and Flore, 1982): photosynthetic photon flux (PPF), 1000 $\mu \mathrm{mol} \cdot \mathrm{m}^{-2} \cdot \mathrm{s}^{-1}$; leaf temperature, $25 \mathrm{C}$; ambient $\mathrm{CO}_{2}$ concentration $\left(\mathrm{C}_{\mathrm{a}}\right), 340$ to 360 $\mu \mathrm{mol} \cdot \mathrm{mol}^{-1}$; and leaf-to-air vapor pressure deficit (VPD), 1.0 to $1.5 \mathrm{kPa}$. Flow rate through an individual chamber was 3.0 liter $\cdot \mathrm{min}^{-1}$. Gas exchange parameters were calculated as described by Moon and Flore (1986).

Two of the four trees were flooded at 2300 HR of day 0 by placing the 7-liter tree containers inside a 12-liter bucket lined with a plastic bag that was then filled slowly with 20 to $22 \mathrm{C}$ tap water sufficient to cover the soil surface $\approx 2 \mathrm{~cm}$ deep. The other two trees remained nonflooded (controls). Oxygen diffusion rates (ODR) were not measured in this experiment, but ODR had been previously verified to decrease to $<0.25 \mu \mathrm{g} \mathrm{O} \mathrm{O}_{2} /$ $\mathrm{cm}^{2}$ per second within a few hours of flooding in the media used (Beckman, 1989). Throughout the experiment, control trees were watered to about container capacity with tap water whenever soil moisture tension was $>20 \mathrm{kPa}$ as measured with a "Quick-Draw" soil moisture probe (Model 2900F; Soil Moisture Equipment Corp., Santa Barbara, Calif.).

Light intensity was adjusted each day (typically between 1700 and $1900 \mathrm{HR}$ ) in six steps from 1000 to $0 \mu \mathrm{mol} \cdot \mathrm{m}^{-2} \cdot \mathrm{s}^{-1} \mathrm{PPF}$. Light levels between 1000 and $200 \mu \mathrm{mol} \cdot \mathrm{m}^{-2} \cdot \mathrm{s}^{-1}$ PPF were obtained by either adjusting the height of the light bank above plants or turning off sets of fluorescent and incandescent lights (in equal proportions). Levels <200 
Table 1. Effects of 1 to 5 days of flooding on apparent quantum yield, dark respiration, and the light compensation point of sour cherry trees.

\begin{tabular}{|c|c|c|c|c|c|}
\hline Day & $\begin{array}{c}\text { Hours } \\
\text { after } \\
\text { flooding }\end{array}$ & Treatment & $\begin{array}{l}\text { Apparent quantum yield } \\
\left(\mathrm{mol} \mathrm{CO}_{2} / \mathrm{mol} \mathrm{PPF}\right)\end{array}$ & $\begin{array}{c}\text { Dark respiration } \\
\left(\mu \mathrm{mol} \mathrm{CO}_{2} / \mathrm{m}^{2} \text { per sec }\right)\end{array}$ & $\begin{array}{c}\text { Light } \\
\text { compensation point } \\
\left(\mu \mathrm{mol} \cdot \mathrm{m}^{-2} \cdot \mathrm{s}^{-1} \mathrm{PPF}\right)\end{array}$ \\
\hline$\overline{0}$ & -7 & $\begin{array}{l}\text { Control } \\
\text { Flooded }\end{array}$ & $\begin{array}{l}0.0213 \\
0.0166^{\mathrm{Ns}}\end{array}$ & $\begin{array}{l}0.44 \\
0.50^{\mathrm{NS}}\end{array}$ & $\begin{array}{l}12 \\
19^{\mathrm{NS}}\end{array}$ \\
\hline 1 & 13 & $\begin{array}{l}\text { Control } \\
\text { Flooded }\end{array}$ & $\begin{array}{l}0.0261 \\
0.0195^{\mathrm{NS}}\end{array}$ & $\begin{array}{l}0.58 \\
0.95^{* *}\end{array}$ & $\begin{array}{l}14 \\
36^{*}\end{array}$ \\
\hline 2 & 43 & $\begin{array}{l}\text { Control } \\
\text { Flooded }\end{array}$ & $\begin{array}{l}0.0173 \\
0.0106^{\text {NS }}\end{array}$ & $\begin{array}{l}0.49 \\
0.59^{\mathrm{Ns}}\end{array}$ & $\begin{array}{l}17 \\
41^{\mathrm{NS}}\end{array}$ \\
\hline 3 & 67 & $\begin{array}{l}\text { Control } \\
\text { Flooded }\end{array}$ & $\begin{array}{l}0.0189 \\
0.0132^{\mathrm{Ns}}\end{array}$ & $\begin{array}{l}0.42 \\
0.65^{\mathrm{NS}}\end{array}$ & $\begin{array}{c}8 \\
34^{\mathrm{NS}}\end{array}$ \\
\hline 4 & 91 & $\begin{array}{l}\text { Control } \\
\text { Flooded }\end{array}$ & $\begin{array}{l}0.0153 \\
0.0095^{*}\end{array}$ & $\begin{array}{l}0.53 \\
0.56^{\mathrm{NS}}\end{array}$ & $\begin{array}{l}20 \\
42^{\mathrm{NS}}\end{array}$ \\
\hline 5 & 115 & $\begin{array}{l}\text { Control } \\
\text { Flooded }\end{array}$ & $\begin{array}{l}0.0145 \\
0.0073^{*}\end{array}$ & $\begin{array}{l}0.46 \\
0.65^{\mathrm{NS}}\end{array}$ & $\begin{array}{l}18 \\
60^{*}\end{array}$ \\
\hline
\end{tabular}

Ns,*,**Nonsignificant or significant at $P=0.05$ or 0.01 , respectively, relative to control at each flooding duration ( $t$ or $\mathrm{F}$ test).

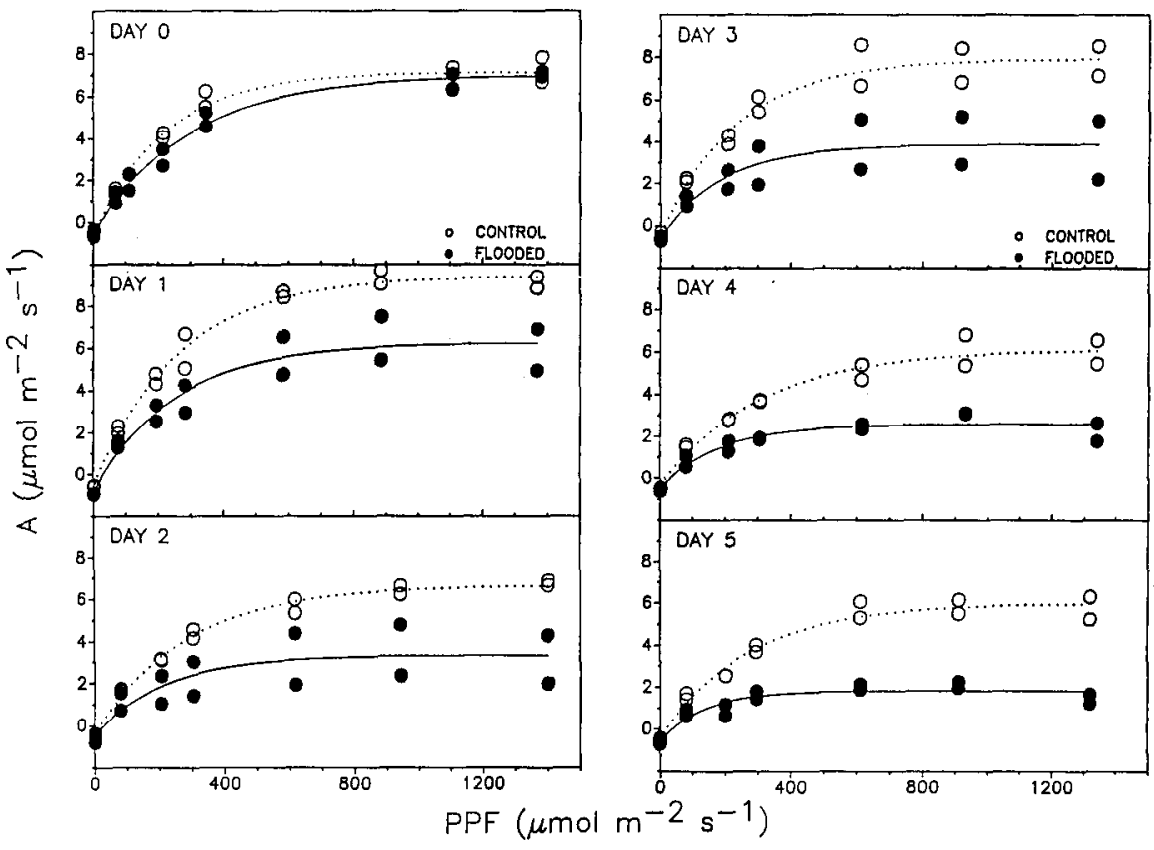

Fig. 3. Net $\mathrm{CO}_{2}$ assimilation (A) as a function of incident photosynthetic photon flux in sour cherry trees before and during 5 days of flooding (all regressions significant at $P<0.05$ ).

$\mu \mathrm{mol} \cdot \mathrm{m}^{-2} \cdot \mathrm{s}^{-1} \mathrm{PPF}$ were attained by placing various neutral density filters over chambers as described by Sams and Flore (1982), and dark respiration was measured with all chamber lights turned off. Leaves were allowed to equilibrate for 10 to $15 \mathrm{~min}$ at each light level before gas exchange measurements. Apparent quantum yields were estimated from the linear portion of the light response curves (Ehleringer and Bjorkman, 1977), as were light compensation points.

Carbon dioxide response curves (Expt. 2). Four selected trees were brought from the glasshouse to the laboratory and placed under 400-W high-pressure sodium vapor lamps in a hood [mean for air, 23C; $20 \%$ to $30 \%$ $\mathrm{RH}$; PPF at midshoot $\approx 900 \mu \mathrm{mol} \cdot \mathrm{m}^{-2} \cdot \mathrm{s}^{-1}$ (12-h photoperiod, 0800-2000 HR)]. Flooding was -imposed on two trees the evening of day 0 as described above and $\mathrm{CO}_{2}$ response determined 2 and 5 days later by placing plants in a walk-in growth chamber $(\approx 900$ HR) under conditions described in Expt. 1.

Plants were allowed to equilibrate for 1 to $2 \mathrm{~h}$ at $\approx 350 \mu \mathrm{mol} \mathrm{CO} / \mathrm{mol}$ and VPD of 2.0
$\mathrm{kPa}$. Carbon dioxide concentration was adjusted in seven steps from $\approx 0$ to $625 \mu \mathrm{mol}$ $\mathrm{CO}_{2} / \mathrm{mol}$ as described by Sams and Flore (1982), except that proportions of each component were controlled by a Multiple Dyna Blender equipped with mass-flow controllers. Carbon dioxide was monitored on the reference side of the system using a portable IR gas analyzer (Model LCA-2, Analytical Development). Carbon dioxide depletion rates were allowed to stabilize 15 to $30 \mathrm{~min}$ at each $\mathrm{CO}$, concentration before data collection. Carbon dioxide response curves were typically determined between 1030 and 1330 HR on each date. Stomatal limitations to A were estimated from A vs. C response curves as suggested by Farquhar and Sharkey (1982).

Vapor pressure deficit response (Expt. 3). Four selected trees were brought to the laboratory from the glasshouse and placed in a hood as described in Expt. 2. Flooding was imposed on two trees in the evening of day 0 and the VPD response determined 2 and 5 days later by placing plants in a walk-in growth chamber $(\approx 900 \mathrm{HR})$ under conditions

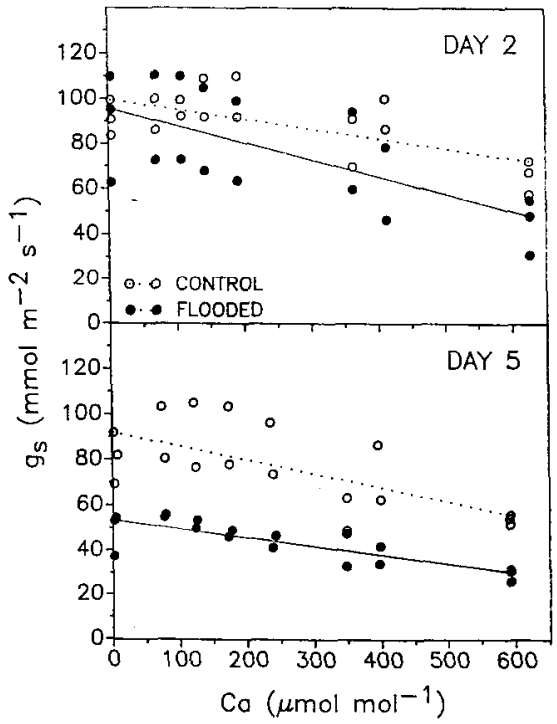

Fig. 4. Stomatal conductance to $\mathrm{CO}_{2}\left(\mathrm{~g}_{s}\right)$ as a function of ambient $\mathrm{CO}_{2}\left(\mathrm{C}_{\mathrm{a}}\right)$ in sour cherry trees after 2 and 5 days of flooding (all regressions significant at $P<0.01$ ). Fitted lines: Day 2, control: $\mathrm{g}_{\mathrm{s}}=99.5-0.0431 \cdot \mathrm{C}_{\mathrm{a}}, r^{2}=0.38$; flooded: $g_{s}=95.5-0.0753 \cdot C_{n}, r^{2}=0.38$. Day 5, control: $\mathrm{g}_{\mathrm{s}}=91.8-0.0606 \cdot \mathrm{C}_{\mathrm{a}}, r^{2}=$ 0.38 ; flooded: $\mathrm{g}_{\mathrm{s}}=53.3-0.0384 \cdot \mathrm{C}_{\mathrm{a}}, r^{2}=$ 0.60 .

of Expt. 1, except for VPD, flow rate, and leaf temperature imposed within individual leaf chambers. Plants were initially allowed to stabilize for $1 \mathrm{~h}$ at $\approx 1.0 \mathrm{kPa}$ VPD (flow rate of 3.0 liters $\cdot \mathrm{min}^{-1}$ and leaf temperature of $27 \mathrm{C}$ ). VPD was varied from $\approx 0.7$ to 3.0 $\mathrm{kPa}$ by changing the dewpoint of the air entering the chamber and/or adjusting the flow through individual chambers. VPDs $>2.5 \mathrm{kPa}$ were attained by raising leaf temperature to $\approx 29$ C. Leaves were allowed to stabilize at each setting for $\approx 15$ to $20 \mathrm{~min}$ before data collection.

A completely randomized design was used in all experiments with two single-plant replications for each of the two treatments: flooded and nonflooded trees. Fitted curves were calculated with Plotit Interactive Graphics and Statistics Package (Scientific Programming Enterprises, Haslett, Mich.). Treatment differences were analyzed by analysis of variance (MSTAT, 1985; SAS, 


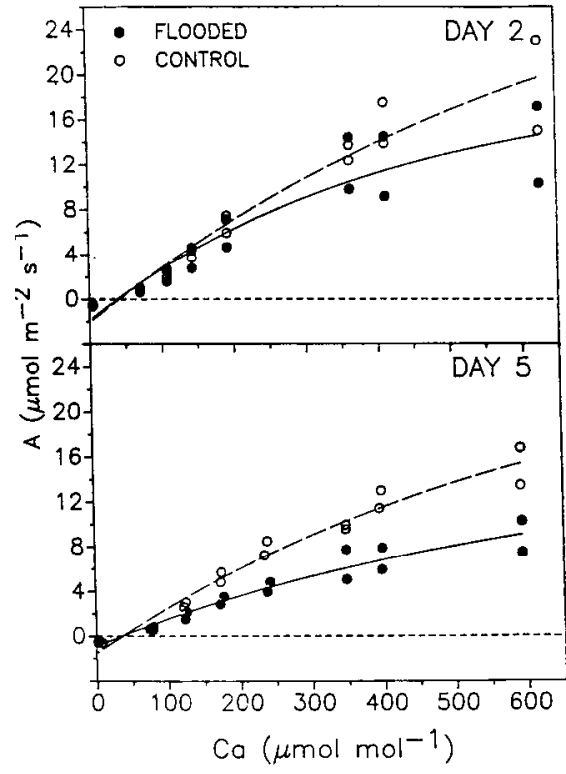

Fig. 5. Net $\mathrm{CO}_{2}$ assimilation (A) as a function of ambient $\mathrm{CO}_{2}\left(\mathrm{C}_{\mathrm{a}}\right)$ in sour cherry trees after 2 and 5 days of flooding. Dashed lines $=$ control; solid lines $=$ flooded trees. All regressions significant at $P<0.01$. Fitted curves: Day 2, control: $\mathrm{A}=35.9-38.0 \cdot e^{(-0.6014 \mathrm{Ca})}, r^{2}=$ 0.93 ; flooded: $\mathrm{A}=19.3-21.2 \cdot \mathrm{e}^{(-0.00(24 \mathrm{Ca})}$, $r^{2}=0.87$. Day 5, control: $\mathrm{A}=26.6-$ $28.1 \cdot \mathrm{e}^{(-0.0016 \mathrm{Ca})}, r^{2}=0.97$; flooded: $\mathrm{A}=15.1$ $-15.9 \cdot \mathrm{e}^{(-0.6016 \mathrm{Ca})}, r^{2}=0.93$.

\section{7) or $t$ test as appropriate.}

Net $\mathrm{CO}_{2}$ assimilation of flooded trees was reduced compared with controls $<12 \mathrm{~h}$ after onset of flooding (Fig. 1). Differences between control and flooded plants generally increased as flooding progressed. At 5 days, A of flooded plants was only $32 \%$ that of controls.

Net $\mathrm{CO}_{2}$ assimilation displayed a diurnal trend with control trees generally reaching A, between 1100 and $1300 \mathrm{HR}$ each day and slowly declined through the remainder of the day (Fig. 1). In flooded trees, however, $A_{\max }$ was generally observed at the first measurement of each day (0900 HR), followed by a slow decline throughout the day.

The response of residual conductance to $\mathrm{CO}_{2}\left(\mathrm{~g}_{\mathrm{r}}^{\prime}\right)$ to flooding resembled that observed for $\mathrm{A}$ with consistent reductions in $\mathrm{g}_{\mathrm{r}}{ }^{\prime}$ of flooded plants compared to controls at 3 days (Fig. 2). Neither $g_{s}$ nor $C_{i}$ was significantly affected by flooding during the experiment (data not shown).

Since the initial decline of $\mathrm{A}$ in flooded plants was not accompanied by a significant drop in either $\mathrm{g}_{\mathrm{s}}$ or $\mathrm{g}_{\mathrm{r}}$ d during day 1 of flooding, it is not clear whether stomatal or nonstomatal limitations of A are primarily responsible. However, as flooding continued the marked decline in $\mathrm{g}_{\mathrm{r}}^{\prime}$ in the absence of significant changes in $\mathrm{g}_{\mathrm{s}}$ and $\mathrm{C}_{\mathrm{i}}$ suggests that nonstomatal limitations of A were dominant.

Davies and Flore (1986a, 1986c) suggested that the initial decline of $\mathrm{A}$ in flooded blueberries appeared to be primarily mediated by stomatal closure since $\mathrm{C}_{\mathrm{i}}$ also declined. However, as flooding continued, the reduction in $\mathrm{A}$ appeared to be due to de-

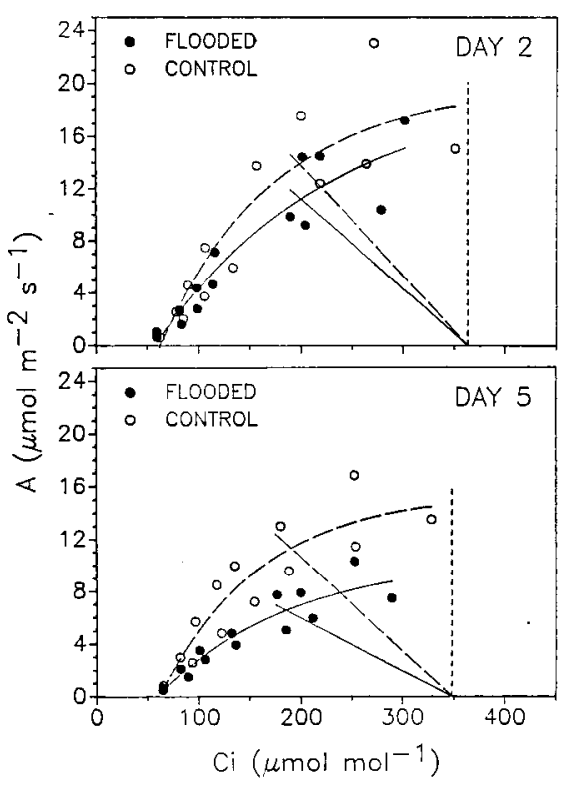

Fig. 6. Net $\mathrm{CO}_{2}$ assimilation rate (A) as a function of intercellular $\mathrm{CO}_{2}\left(\mathrm{C}_{i}\right)$ in sour cherry trees after 2 and 5 days of tlooding. Dashed lines = controls; solid lines = flooded trees. Curves represent "demand function"; straight lines represent "supply function." Dotted vertical lines represent supply curves for infinite $g_{s}$. Demand curves: Day 2, control: $\mathrm{A}=19.8-$ $34.4 \cdot \mathrm{e}^{(-0.0088 \mathrm{Ci})}, r^{2}=0.84$; flooded: $\mathrm{A}=20.1$ $-27.8 \cdot \mathrm{e}^{(-0.0057 \mathrm{Ci})}, r^{2}=0.87$. Day 5, control: $\mathrm{A}=15.5-28.7 \cdot \mathrm{e}^{(-0.0101 \mathrm{Ci})}, r^{2}=0.86$; flooded: $\mathrm{A}=10.5-16.5 \cdot \mathrm{e}^{(-0.0077 \mathrm{Ci})}, r^{2}=$ 0.87 . Supply curves: Day 2, control: $A=$ $0.084 \cdot\left(363-C_{i}\right)$; flooded: $A=0.069 \cdot(363$ $\left.-C_{i}\right)$. Day 5, control: $A=0.072 \cdot\left(348-C_{i}\right)$; flooded: $A=0.040 \cdot\left(348-C_{i}\right)$.

creases in both $\mathrm{g}_{s}$ and $\mathrm{g}_{\mathrm{r}}$. In contrast, Smith and Ager (1988) concluded that, in pecan [Carya illinoinensis (Wangenh.) K. Koch] seedlings subjected to soil flooding, reduction in A was primarily due to loss of $\mathrm{CO}_{2}$ assimilation capacity, since $\mathrm{C}_{\mathrm{i}} \mathrm{did}$ not decline in flooded plants throughout the treatment period.

Both treatments were light saturated at $\approx 600$ to $800 \mu \mathrm{mol} \cdot \mathrm{m}^{-2} \cdot \mathrm{s}^{-1} \mathrm{PPF}$ before the start of flooding (Fig. 3). This saturation light level is lower than that reported previously for sour cherry (Sams and Flore, 1982), possibly a result of having grown the trees in a partially shaded environment. Flooded trees displayed reduced A at all light levels following imposition of flooding through the end of the experiment. From days 2 to 5 , the light saturation point of flooded trees gradually dropped to $\approx 400 \mu \mathrm{mol} \cdot \mathrm{m}^{-2} \cdot \mathrm{s}^{-1} \mathrm{PPF}$.

Apparent quantum yield decreased gradually in flooded plants, becoming significantly different from controls at 4 days (Table 1). At 5 days, quantum yield of flooded plants was only $52 \%$ that of controls. Davies and Flore (1986a) observed a more rapid decrease in quantum yield during soil flooding of blueberries (Vaccinium ashei Reade). Dark respiration was markedly increased in flooded trees after 1 day of flooding (166\% of control rate) but did not remain significantly higher through the end of the experiment (Table 1). Light compensation points were higher in

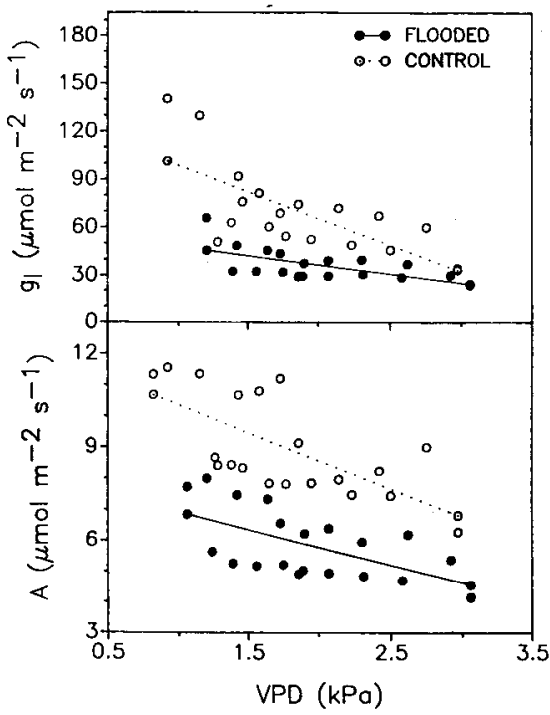

Fig. 7. Stomatal conductance to water $\left(\mathrm{g}_{1}\right)$ and net $\mathrm{CO}_{2}$ assimilation rate $(\mathrm{A})$ as functions of vapor pressure deficit (VPD) in sour cherry trees after 5 days of flooding (all regressions significant at $P<0.01$ ). Fitted lines: control: $g_{1}=$ 131.9 - 33.3.VPD, $r^{2}=0.47$; flooded: $\mathrm{g}_{1}=$ 59.4 - 11.4.VPD, $r^{2}=0.37$; control: $\AA=$ $12.2-1.8 \cdot \mathrm{VPD}, r^{2}=0.45$; flooded: $\mathrm{A}=$ $8.1-1.1 \cdot V P D, r^{2}=0.35$.

flooded plants the day following imposition of flooding, but differences moderated until day 5 (Table 1 ), possibly reflecting changes in quantum yields and dark respiration of the two treatments.

Response of $\mathrm{g}_{\mathrm{s}}$ to varying $\mathrm{C}_{\mathrm{a}}$ after 2 and 5 days of flooding in the second experiment is shown in Fig. 4. On both occasions, $g_{s}$ of flooded and control trees displayed a negative linear response to increasing $\mathrm{C}_{\mathrm{a}}$. By 5 days, $\mathrm{g}_{\mathrm{s}}$ of flooded trees had been reduced compared with that of controls at all VFDs. Moreover, the slope of the fitted line was significantly less negative in flooded trees after 5 days of flooding than it had been after 2 days $(P<0.001)$, indicating a decrease in stomatal responsiveness to $\mathrm{C}_{\mathrm{a}}$ in flooded trees. Davies and Flore (1986b) observed a similar pattern for blueberries subjected to short-term flooding.

Net assimilation of $\mathrm{CO}_{2}$ of flooded plants was numerically lower at 2 days than that of controls at all $\mathrm{C}_{\mathrm{a}}$ higher than $\approx 100 \mu \mathrm{mol}$ $\mathrm{CO}_{2} / \mathrm{mol}$ (Fig. 5). At 5 days, A of flooded plants was numerically lower than that of controls at all $\mathrm{C}_{2}$ higher than $\approx 65 \mu \mathrm{mol} \mathrm{CO}_{2} /$ mol. Davies and Flore (1986b) observed a similar decrease in the response of A to increasing $\mathrm{C}_{\mathrm{a}}$ of flooded blueberries.

The relationship between $\mathrm{A}$ and $\mathrm{C}_{\mathrm{i}}$ (Fig. 6 ) for flooded and control trees after 2 and 5 days of flooding was similar to that between $\mathrm{A}$ and $\mathrm{C}_{\mathrm{a}}$. Estimates of stomatal limitations to A on day 2 were $24.8 \%$ and $32.5 \%$ for control and flooded trees, respectively, and on day 5 were $22.8 \%$ and $29.9 \%$, respectively. The relative contribution of increased stomatal limitations to the observed reduction in A of flooded plants was estimated by assuming that flooded plants had stomatal limitations similar to those of con- 
trols and solving for A in the model of Farquhar and Sharkey (1982). This procedure resulted in estimates of $\mathrm{A}$ in flooded plants (without additional stomatal limitations) of 12.4 and $7.2 \mu \mathrm{mol} \mathrm{CO} / \mathrm{m}^{2}$ per second, on days 2 and 5, respectively. When these estimates were compared with observed $\mathrm{A}$ of control plants (i.e., 13.9 and $11.3 \mu \mathrm{mol} \mathrm{CO}_{2} /$ $\mathrm{m}^{2}$ per second) and $\mathrm{A}$ of flooded plants (i.e., 11.2 and $6.6 \mu \mathrm{mol} \mathrm{CO}_{2} / \mathrm{m}^{2}$ per second) on days 2 and 5, respectively, we found that increased stomatal limitations accounted for $\approx 48 \%$ and $13 \%$ of the observed depression in A of flooded plants on days 2 and 5, respectively. Thus, it appeared that increased stomatal limitations were initially an important factor in reducing $\mathrm{A}$ in flooded plants but that as flooding continued, nonstomatal limitations became dominant. Davies and Flore (1986b) observed a similar change in stomatal and nonstomatal limitations during flooding of blueberries.

However, our interpretations of the $\mathrm{A} / \mathrm{C}_{\mathrm{i}}$ curves must be viewed cautiously in light of a recent report by Downton et al. (1988) suggesting that this method of estimating $\mathrm{C}_{\mathrm{i}}$ is invalid if stomata on various parts of a leaf behave very differently. In such a case, gas exchange data may overestimate $\mathrm{C}_{\mathrm{i}}$, which, in turn, would lead to an overestimation of nonstomatal limitations to A. The determination of the uniformity of stomata behavior during soil flooding in sour cherries or an estimate of $\mathrm{C}_{\mathrm{i}}$ not based on gas exchange data, i.e., fluorescence-derived $\mathrm{C}_{\mathrm{i}}$ measurements, would be very helpful in clarifying this issue.

Response of A and stomata1 conductance to water vapor $(\mathrm{g}$ ) to varying VPDs in Expt. 3 was similar for control and flooded plants at 2 days, displaying a negative linear response with increasing VPD (Fig. 7). However, at 5 days the slopes of the $\mathrm{g}_{1}$ and $\mathrm{A}$ vs. VPD response lines were significantly less negative for flooded trees than for controls $(P<0.05)$, indicating a decrease in stomatal responsiveness to VPD in flooded trees. Similar responses to VFD were observed by Davies and Flore (1986c) for blueberries subjected to flooding.

In summary, over 5 days of soil flooding, $\mathrm{A}, \mathrm{g}_{\mathrm{r}}^{\prime}$, and $\Phi$ in sour cherry trees were markedly reduced. Initially, stomatal and nonstomatal limitations to A may be of about equal importance. However, as flooding continues nonstomatal limitations appear to become dominant.

\section{Literature Cited}

Andersen, P.C., P.B. Lombard, and M.N. Westwood. 1984a. Leaf conductance, growth and survival of willow and deciduous fruit tree species under flooded soil conditions. J. Amer. Soc. Hort. Sci. 109:132-138.

Andersen, P.C., P.B. Lombard, and M.N. Westwood. 1984b. Effect of root anaerobiosis on the water relations of several Pyrus species. Physiol. Plant. 62:245-252

Beckman, T.G. 1989. Flooding tolerance of sour cherries. PhD Diss., Abstr. Int. 50(12):5408B5409B, DA9011963, Michigan State Univ., East Lansing.

Crane, J.H. and F.S. Davies. 1989. Flooding responses of Vaccinium species. HortScience 24(2):203-210

Davies, F.S. and J.A. Flore. 1986a. Short-term flooding effects on gas exchange and quantum yield of rabbiteye blueberry (Vaccinium ashei Reade). Plant Physiol. 81:289-292.

Davies, F.S. and J.A. Flore. 1986b. Flooding, gas exchange and hydraulic root conductivity of highbush blueberry. Physiol. Plant, 67:545-551.

Davies, F.S. and J.A. Flore. 1986c. Gas exchange and flooding stress of highbush and rabbiteye blueberries. J. Amer. Soc. Hort. Sci. 111:565571

Downton, W.J.S., B.R. Loveys, and W.T.R. Grant. 1988. Stomata1 closure fully accounts for the inhibition of photosynthesis by abscisic acid. New Phytologist 108:263-266.

Ehleringer, J. and O. Bjorkman. 1977. Quantum yields for $\mathrm{CO}_{2}$ uptake in $\mathrm{C}_{3}$ and $\mathrm{C}_{4}$ plants. Plant Physiol. 59:86-90.

Farquhar, G.D. and T.D. Sharkey. 1982. Stomatal conductance and photosynthesis. Annu.
Rev. Plant Physiol. 33:317-345.

Farquhar, G.D. and S. von Caemmerer. 1982. Modeling of photosynthetic response to environmental conditions, p. 549-587. In: O.L. Lange, P.S. Nobel, C.B. Osmond, and H. Ziegler (eds.). Physiological ecology II, Encyclopedia of plant physiology. New series, vol. 12B. Springer-Verlag; Berlin.

Farquhar, G.D., S. von Caemmerer, and J.A. Berry. 1980. A biochemical model of photosynthetic $\mathrm{CO}_{2}$ assimilation in leaves of $\mathrm{C}_{3}$ species. Planta 149:78-90.

Howitt, A.J., A.L. Jones, and J. Hull. 1987. Fruit spraying calendar. Michigan State Univ., Coop. Ext. Serv., East Lansing. Ext. Bul. E-154.

Jones, H.G. 1973. Limiting factors in photosynthesis. New Phytol. 72:1089-1094.

Moon, J.W., Jr., and J.A. Flore. 1986. A BASIC computer program for calculation of photosynthesis, stomatal conductance and related parameters in an open gas exchange system. Photosyn. Res. 7:269-279.

MSTAT. 1985. Version 4.0. Michigan State Univ., East Lansing.

Phung, H.T. and E.B. Knipling. 1976. Photosynthesis and transpiration of citrus seedlings under flooded-conditions. HortScience 11:131-133.

Sams, C.E. and J.A. Flore. 1982. The influence of age, position, and environmental variables on net photosynthetic rate of sour cherry leaves. J. Amer. Soc. Hort. Sci. 107:339-344.

SAS. 1987. SAS/STAT guide for personal computers. version 6 ed. SAS Inst., Cary, N.C.

Schaffer, B. and R.C. Ploetz. 1989. Net gas exchange as a damage indicator for Phytophthora root rot of flooded and nonflooded avocado. HortScience 24:653-655.

Smith, M.W. and P.L. Ager. 1988. Effects of soil flooding on leaf gas exchange of seedling pecan trees. HortScience 23:370-372.

Syvertsen, J.P., R.M. Sablotovicz, and M.L. Smith. 1983. Soil temperature and flooding effects on two species of citrus: I. Plant growth and hydraulic conductivity. Plant \& Soil 72:312 .

von Caemmerer, S. and G.D. Farquhar. 1981. Some relationships between the biochemistry of photosynthesis and gas exchange of leaves. Planta 153:376-387. 